J. Japan. Assoc. Min.

Petr. Econ. Geol.

$75, \quad 196-202,1980$

\title{
NOTES ON PETROGRAPHY AND ROCK-FORMING MINERALOGY (7) ZONAL STRUCTURE OF ALBITE PORPHYROBLAST FROM BASIC SANBAGAWA SCHISTS IN CENTRAL SHIKOKU
}

\author{
Masayuki Otsuki \\ Geological Institute, Faculty of Science, University of Tokyo. Hongo, 113. Tokyo
}

\begin{abstract}
Albite porphyroblasts consist of the core rich in inclusions and the clear rim free from them. Compositional maps of An content of albite porphyroblasts show that the albite is zoned, and the types of zoning are different between the core and clear rim. The clear rim grew around the core preferentially along the lineation. The compositional maps and the microscopic observations show that the core of the porphyroblost was originally constructed of the aggregate of minute grains. There are two types of zonal structure of albite porphyroblasts: one is the simple type in which the An content decreases from the core to the clear rim, and the other is the complex type in which the An content docreases from the conter to margin within the core, but it increases in the clear rim and again decreases at the outermost part of the clear rim. The variation of An content is very small, from about 0 to 3 An per cent, and even the An-richest composition is still alluite in plagioclase nomenclature. The difference of zonal structures between the complex and simple types suggests that the formational stages of the porphyroblasts were different.
\end{abstract}

\section{INTRODUGTION}

Albite is a main constituent of the Sanbagawa metamorphic rocks. Many geologists have divided the Sanbagawa metamorphic belt into two zones, i.e., the spotted and non-spotted zones based on the presence and absence of albite porphyroblasts.

Recent study of albite porphyroblasts was commenced by Toriumi $(1975 \mathrm{a}$, b) who proposed a dynamic model for their origin that the porphyroblasts grew by collision and annealing of minute albite grains. $\mathrm{He}$ also showed that the compositional range of epidotes included in the porphyroblasts is nearly equal to that of epidotes in the matrix. Itaya (1978) found that retrograde
$\mathrm{TiO}_{2}$-minerals are often included in the porphyroblasts. Hosotani (in press) concluded that the zonal structure of garnets included in the porphyroblasts is the same as that of garnets in the matrix. Based on these facts, Itaya and Hosotani have considered that albite porphyroblasts were formed during the retrograde stage of the Sanbagawa metamorphism. Hara et al. (1977) and Takagi and Hara (1979) have also attempted to clarify the formational stage of albite prophyroblasts using the fabric of the porphyroblasts and chemical information of amphibole inclusions in them. They have concluded that the formational stage of the clear rim (the mantle in their papers) coincided with the maximum temperature 
phase of metamorphism.

The chemical compositions of albite in the Sanbagawa metamorphic belt have been reported by several authors, Ernst et al. (1970), Kurata and Banno (1974), Toriumi (1975a) and Watanabe (1977). Their data suggest that the anorthite content of albite increases with advancing metamorphic grade, but only slightly from about 0.1 to about 3 An per cent. Kurata and Banno (ibid.) have noticed that different porphyroblasts could have slightly different compositions in one specimen, where an albite porphyroblast has about 0.5 An per cent and another 0.95 An per cent, but did not pursure further investigation.

During the petrologic works of basic schists of the Asemi River area, belonging to the Sanbagawa metamorphic belt in central Shikoku, the present author has noticed that albite prophyroblasts have significant zonal structures. The zonal structure of albite porphyroblast gives important information in deciphering the growth history of albite porphyroblasts. In the following, the present author intends to describe the zonal structures of albite porphyroblasts from the Asemi River area with some petrologic discussions.

\section{OUTLINE OF GEOLOGY}

Recently the zonal mappings of the Sanbagawa metamorphic belt in central Shikoku were performed by Kurata and Banno (1974), Higashino (1975), Higashino et al. (1977) and Banno et al. (1978). The metamorphic zonal map of central Shikoku is shown in Fig. 1. The mineral zones in the figure are the chlorite, garnet and biotite zones in the ascending order of metamorphic grade and are difined by the mineral parageneses in the pelitic schists. The

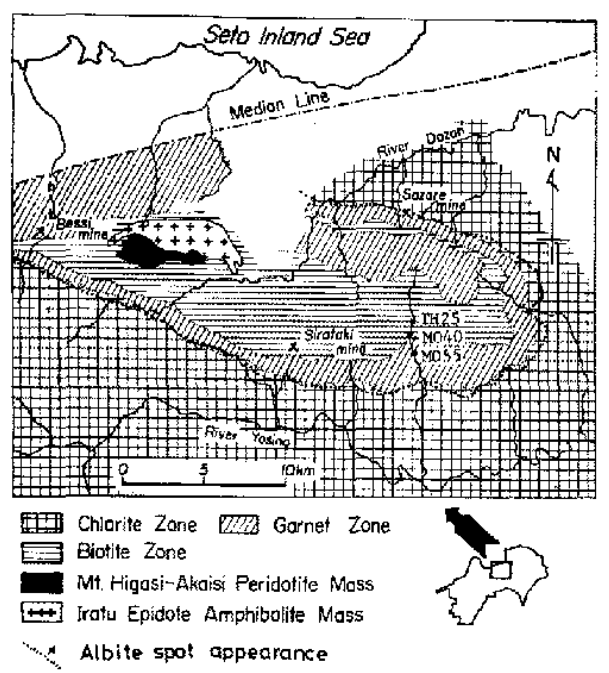

Fig. 1. Metamorphic zonal map of central Shikoka, modified after Higashino et al. (1977). Sample Jocalities are shown.

non-spotted zone comprises almost all the chlorite zone, and the spotted zone does the garnet and biotite zones and a part of the chlorite zonc. Hence, the spotted zone belongs to the higher grade part of the Sanbagawa metanorphic belt same as in the other areas of the belt. In basic rocks, albite porplyyroblasts are conspicuous as white patches.

\section{Mode of Occurrence of ALBIte Porphyroblast}

The zonal structures of albite porphyroblasts were studied in the basic schists along the Asemi River (Fig. 1). Albites in the non-spotted zone are almost pure albite, up to 0.5 An per cent, and do not have zonal structures, but albite porphyroblasts in the spotted zone are commonly zoned. Typical examples of such zonal structures will be described in this paper. Three specimens TH25, MO4O and MO55 studied in details belong to the higher biotite zone, the lower 
(a)

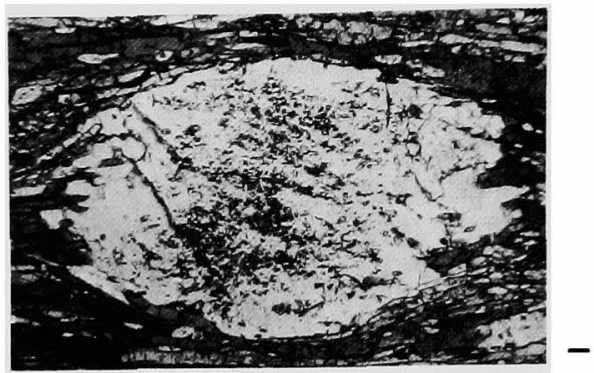

(b)

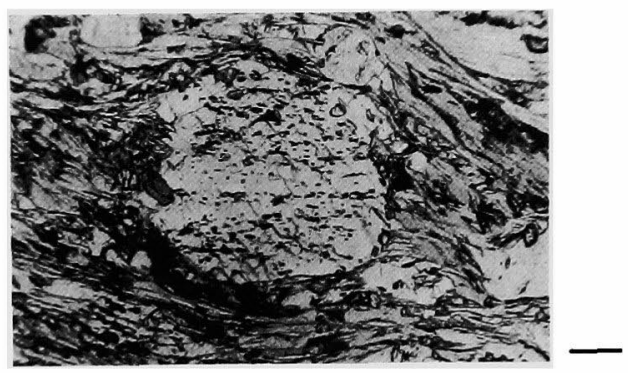

(c)
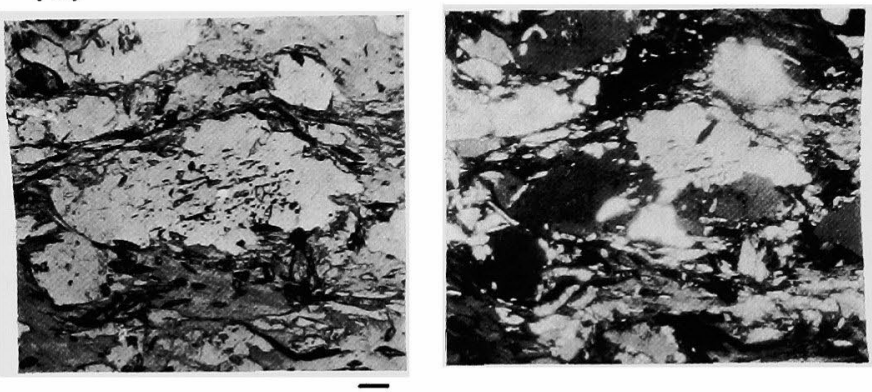

Fig. 2. Photomicrographs of albite porphyroblasts which were cut parallel to tectonic b-c axes. Scale bars show $0.1 \mathrm{~mm}$. The core rich in inclusions and the clear rim free from inclusions are well distinguished, and the boundary between them is rather sharp. a: TH25, open !nicol. The clear rim develops well parallel to the lineation, but is poor or absent perpendicular to the lineation. b: MO55, open nicol. The core can be divided into two parts on the basis of the abundance of inclusions. The clear rim does not develop well in this albite porphyroblast. c: MO40, the left hand is open nicol and the right hand is crossed nicols. The clear rim develops well parallel to the lineation. This albite porphyroblast can be divided into four parts on the basis of the difference of extinction positions.

biotite zone and the garnet zone, respectively (Fig. 1). The mineral assemblages of $T H 25$, MO40 and MO55 are hornblende+epidote chlorite + stilpnomelane + sphene + rutile + ilmenite + pyrite, hornblende + epidote + chlorite + tourmaline + sphene + rutile + hema- tite+ilmenite, and hornblende+epidote + chlorite + apatite + calcite + sphene + magnetite + hematite + ilmenite + chalcopyrite, respectively. Albite, quartz and muscovite are ubiquitous in these specimens. The photomicrographs of albite porphyroblasts in these 
specimens which were cut parallel to $b-c$ tectonic axes are shown in Fig. 2. The mean grain-size of albite porphyroblasts is $0.68 \times 0.29 \mathrm{~mm}^{2}$ on $M O 55,0.88 \times 0.54 \mathrm{~mm}^{2}$ on $M O 40$ and $1.7 \times 0.86 \mathrm{~mm}^{2}$, on TH25. Grain size of albite porphyroblast increases with increasing metamorphic grade.

Albite porphyroblasts consist of the core rich in inclusions and the clear rim free from inclusions. The boundary between the two is rather sharp. Becke lines, however, could not be observed at the boundary. Every phase of basic schists is included in albite porphyroblasts, but common inclusions are epidote, amphiboles, sphene, rutile, ilmenite and hematite. On the other hand, chlorite, muscovite and calcite are usually absent in albite porphyroblasts. The distributions of inclusions in albite porphyroblasts are rather heterogeneous, as is most distinct in specimen MO55 where the core of the porphyroblast can be divided into two parts on the basis of the abundance of inclusions (Fig. 2b). The clear rims are well developed along the lineation defined by the arrangement of elongated minerals such as hornblende, chlorite and muscovite, but poor or absent along the direction perpendicular to the lineation. Albite porphyroblasts of TH25 and MO55 are optically homogeneous, and the extinction position is the same within the grain and twining is absent. On the other hand, an albite porphyroblast of $\mathrm{MO} 40$ is divided into four parts by the difference of extinction positions (Fig. 2c). Optically homogeneous albite porphyroblasts, however, are also contained in this specimen.

\section{Zonal Structure of Albite Porphyroblast}

The compositional maps of albite porphyroblasts in three specimens $T H 25$,

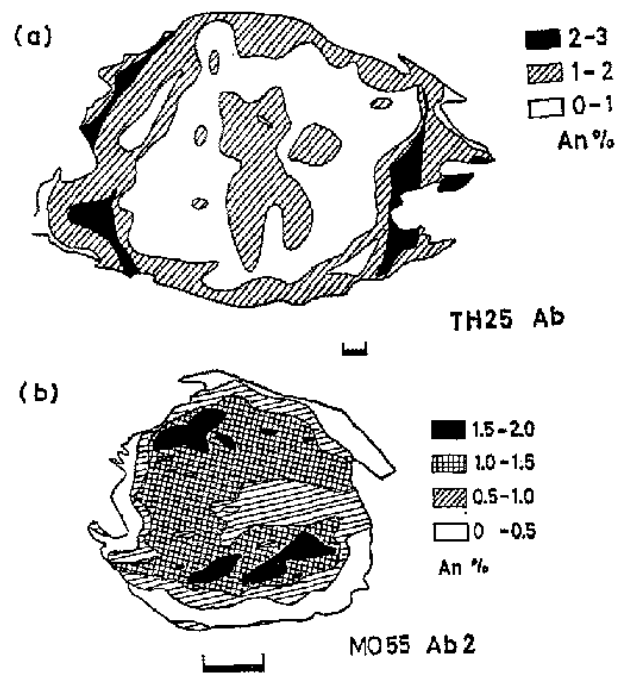

(c)

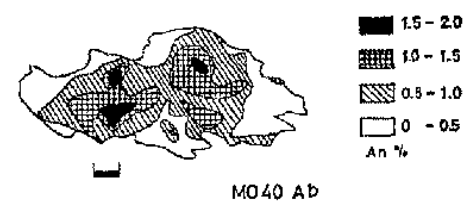

Fig. 3. The compositional maps of albite porphyroblasts which are shown in Fig. 2. There are two types of zonal structures: One is the complex type of (a) TH25, and the other is the simple type of (b) MO55 and (c) MO 40. Explanations are given in text.

MO40 and MO55 are shown in Fig. 3. The maps were constructed on the partial analyses of 354 points for $T H 25,130$ for MO4O and 288 for MO55. The analyzed points were selected on the glid of tens of micron interval, but in analyzing the cores of the porphyroblasts, which contain abundant inclusions, the points were selected carefully to avoid the contamination by the inclusions. The analytical error is about \pm 0.2 An per cent. The variation of An content of the porphyroblasts is only from nearly 0 to 3 An per cent, but is distinct. The orthoclase component is always less than 0.3 per cent, and no zonal structure in regard to $\mathrm{K}$ could be recognized. 
The zonal structure of the porphyroblast in TH2S is as follows: The An content is about 1.5 per cent at the center of the core and decreases towards the margin of the core, down to 0.5 per cent at the boundary between the core and clear rim. Entering the clear rim, it increases up to 3 per cent in maximum an intermediate part of the clear rim, but further outwards, it again decreases to 0.3 per cent. The An-rich rim in the compositional map coincides with the clear rim, but the zoning in the clear rim is not concentric, but the area with An more than 2 per cent is arranged subvertical to the schistosity. The zonal structure of the porphyroblasts in MO4O and MO55 is as follows: the core consists of albite with An more than 1 per cent, but no maximum of An content appears in the clear rim. As described above, there are two types of zonal structure, one is the complex type represented by $T H 25$, and the other is the simple type represented by $M O 4 O$ and $M O$ 55 .

Albite porphyroblasts are chemically and optically heterogeneous. The optical heterogeneity is represented by the presence and the absence of inclusions on the one hand, and by the difference in the extinction position on the other, even though the latter is not commonly observed. The former heterogeneity is confirmed by the chemical zoning on the compositional maps, which suggests that the clear rim grew around the core and was formed at the different physical conditions from the core. In specimen MO4O, there are several area with An more than 1 per cent, and they correspond to the parts with the different extinction positions. Thus the core of the porphyroblast in this specimen had been formed by the aggregation of four minute grains with abundant inclusions, which was enclosed by the clear rim. The core of the porphyroblast in specimen MO55 consists of two inclusion rich parts which correspond with areas with An more than 1 per cent, although the porphyroblast shows homogeneous extinction throughout the grain different from the above example. The core of this specimen may be considered as the aggregate of two inclusion-rich grains, which was probably annealed to give homogeneous extinction. Toriumi (1975a, b) has proposed that some albite porphyroblasts had been formed by the collision of a few albite grains, which were later annealed to have led to the homogeneous extinction. He has interpreted the inclusions as being captured during the collision. Even though the albite porphyroblasts described here do not offer the evidence to test Toriumi's idea of the genesis of the inclusions, the growth by collision and later annealing seems to have operated in the examples described here as well.

In addition to the difference in the pattern of chemical zoning, the complex and simple types of albite porphyroblasts have different chemistry of amphibole inclusions. The use of chemical information of inclusion minerals in determining the formational stage of albite porphyroblasts was attempted by Itaya (1978), Takagi and Hara (1979) and Hosotani (in press). The preliminary results of the present author's investigation is described briefly here. The cores of the complex type porphyroblast contain hornblende, while those of the simple type both hornblende and actinolite, even though the host rock contains hematite. Otsuki and Banno (in preparation) have concluded that in hematite-bearing basic schists, the amphibole is crossite in the lower-grade basic schists, and it is replaced by barroisitic hornblende in the higher-grade ones. 
However, the retrograde recrystallization gives rise to the formation of actinolite instead of crossite, suggesting that metamorphic pressure prevailed was higher during the prograde metamorphism than during the retrograde metamorphism. It follows that the core of the simple type of albite porphyroblasts was formed later than that of the complex type of the porphyroblasts. The view that the cores of some albite porphyroblasts were formed during the retrograde metamorphism is in harmony with the observation of Itaya (1978), who has shown that retrograde $\mathrm{TiO}_{2}$-minerals were included in the cores of some albite porphyroblasts. As discussed above, the detailed studies of the compositional zoning of the albite porphyroblasts and of the inclusion mineralogy could cast light to elucidate the thermal history of the Sanbagawa schists. The study along this line is being in progress by the present author.

\section{ACKNOWLEDGEMENTS}

The author sincerely thanks Dr. S. Banno for his continuous encouragement and the critical reading of the manuscript. His thanks are also due to Dr. Y. Nakamura and Dr. M. Toriumi for encouragements and discussions, and Prof. H. Onuki for the critical reading.

\section{REFERENCES}

Banno, S., Higashino, T., Otsuki, M., Itaya, T., and Nakajima, T. (1978) Thermal structure of the Sanbagawa metamorphic belt in central Shikoku. J. Phys. Eathh, 26, suppl., s345s356.

Ernst, W.G., Seki, Y., Ounki, H. and Gilbert, M. (1970) Comparative study of low-grade metamorphism in California Coast Ranges and the outer metamorphic belt of Japan. Mem. Geol. Soc. Am. 124, 276.

Hara, I., Hide, K., Takeda, K., Tsukuda, E., Tokuda, M. and Shiota, T. (1977) Tectonic movement in the Sambagawa belt. The Sambagawa belt, edited by $K$. Hide, Hiroshima University Press, Hiroshima, 307-390. (in Japanese with English abstract).

Higashino, T, (1975) Biotite zone of Sanbagawa metamorphic terrain in the Shiragayama area, central Shikoku, Japan. Jour. Geol. Soc. Japan, 81, 653-670. (in Japanese with English abstract).

-..., Hide, K. and Banno, S. (1977) Metamorphic zone map of the Sanbagawa belt in Sikoku island and Kii peninsula. The Sambagarea belt, edited by $K$. Hide, Hiroshima University Press, Hiroshima, 201-206. (in Japanese with English abstract)

Hosotani, H. (in press) Growth stage of albite porphyroblast in pelitic schists of Sanbagawa metamorphism. Jour. Geol. Soc. Japan. (in Japanese with English abstract).

Itaya, T. (1978) Notes on petrography and rockforming mineralogy (3): Albite porphyroblasts containing $\mathrm{TiO}_{2}$-minerals from Sanbagawa pelitic schists in central Shikoku, Japan. Jouw. Japan. Assoc. Min. Pet. Econ. Geol., 73, 339-345.

Kurata, H. and Banno, S. (1974) Low-grade progressive metamorphism of pelitic schists of the Sazare area, Sanbagawa metamorphic terrain in central Sikoku, Japan. J. Petvol., 15, 361-382.

Takagi, K. and Hara, I. (1979) Relationship between growth of albite porphyroblasts and deformation in a Sambagawa schist, Central Shikoku, Japan. Tectonophysics, 58, 113-125.

Otsuki, M. and Banno, S. (in preparation) The phase equilibrium relations of the hematitebearing basic schists in the Sanbagawa metamorphic belt, central Shikoku, Japan.

Toriumi, M. (1975a) Petrological study of the Sambagawa metamorphic rocks in the Kanto Mountains, central Japan. Bull. Univ. Museum, Univ, Tobyo, 9.

(1975b) A dynamic aspect of metamorphic differentiation. Jour. Geol. Soc. Japan, 81, 505-511. (in Japanese with English abstract).

Watanabe, T. (1977) Metamorphism of the Sambagawa and Chichibu belt in the Oshika district, Nagano prefecture, central Japan. $J$. Fac. Sci. Hokkaido Univ., Ser. IV, 17, 629-694. 


\title{
四国中央部三波川㙁基性片岩中に見られる曹長石斑状变晶の累帯構造
}

\author{
大㭷正行
}

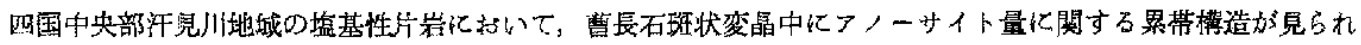

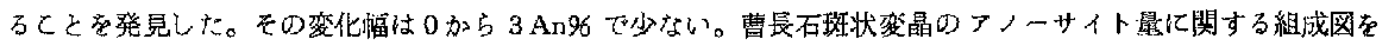

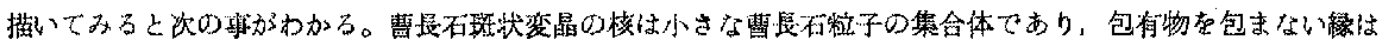

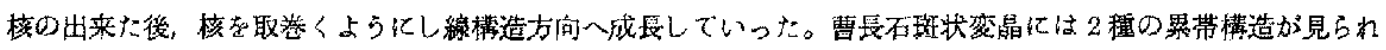

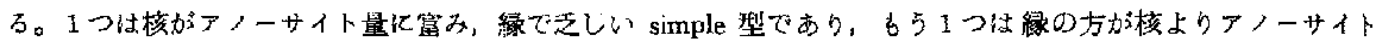

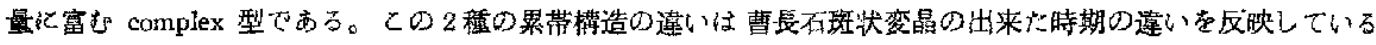
と考えられる。 